\title{
Tid og rum - børn og køn
}

\section{Temporalitet som metodisk og teoretisk dimension i børne/ungdomsforskning og i kønsforskning}

\section{Af Harriet BJerrum Nielsen}

Tiltrædelsesforelæsning

Ålborg Universitet

27. marts 2014

\section{TILTRÆDELSES- FORELÆSNING}

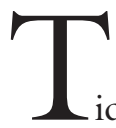

id og rum er kategorier, vi tænker i og som skaber mening og sammenhæng. Det er samtidig også de kategorier, som muliggør, at vi kan opfatte forandring og brud.

Kategorierne har udgjort vigtige dimensioner i mit eget arbejde indenfor kønsforskning og indenfor børne- og ungdomsforskning. Fra et fokus på den rumlige dimension - nemlig at undersøge, hvordan piger og drenge bruger forskellige kommunikationsstrategier, skaber kønnede kulturer og deltager på kønnede måder i undervisningen - er tid blevet en stadig vigtigtigere dimension for mig for at forstå både kønnet og børnene, fordi køn jo ændrer betydning over tid, og børn udvikler sig fra små til store. Det har ført til, at næsten alle mine forskningsprojekter de sidste mange år har kredset omkring tid og ændring. 1 Tidsdimensionen er også blevet central i forskningsdesignene $\mathrm{i}$ form af livshistoriske interviews, generationsstudier og longitudinelle studier. Blandt de to vigtigste projek- 
ter har været en undersøgelse af ungdom i tre generationer, hvor jeg sammen med min kollega Monica Rudberg fra Universitetet i Oslo interviewede generationskæder af døtre, mødre og mormødre og sønner, fædre og farfædre for bedre at kunne forstå, hvordan kønnet ændrer betydning i et subtilt samspil mellem strukturelle, kulturelle og personlige forhold (Nielsen \& Rudberg 2006, Rudberg \& Nielsen 2012). I dette projekt benyttede vi os også af longitudinelle metoder, eftersom yngste generation blev interviewet både som 20- og 30årige og i nogle tilfælde også som 40årige.

I et andet projekt, om piger og drenge fra 1. til 9.klasse, har jeg rendyrket den longitudinelle metode og kombineret den med klasserumsobservation (Nielsen, 2011/ 2009). Her fulgte jeg en norsk skoleklasse gennem årlige observationsperioder, fra de begyndte i l. klasse i 1992 gennem 9 års grundskole for at se, hvilken betydning køn havde fået i skolen i dag, og hvordan det spiller sammen med andre sociale kategorier såsom klasse og etnicitet. Jeg interviewede eleverne igen, efter de var færdige med gymnasiet og var sidste gang i kontakt med dem i 2008, da de var 23 år gamle.

Det teoretiske spørgsmål, der først og fremmest har interesseret mig er forholdet mellem subjektivitet, køn og kultur. Eller som Nancy Chodorow har formuleret det: "[...]stedet hvor det psykologiske moder det kulturelle, eller hvor selvet moder verden" (1999:6). Jeg forstår det sådan, at subjektivitet ikke bare er noget, der afledes af større samfundsmæssige strukturer, men at det selv udgør et aktivt og komplicerende element i samfundsdynamikkerne. Og med det mener jeg ikke, at dette nødvendigvis sker på en intenderet eller bevidst måde, fx gennem politiske identiteter og aktørskab, men at mennesket gennem sin ureflekterede væren og praksis kan være mere eller mindre modtagelig for ændringsmuligheder på forskellige historiske tidspunkter. Nye samfundsmæssige muligheder kan møde en "indre parathed" eller omvendt en følelses- mæssig modstand, som kan være med til at skabe, accelerere eller bremse strukturelle og kulturelle ændringsprocesser. En anden måde at sige dette på er, at også psykologien eller menneskers indre verden er historisk formet, altså en mere vidtrækkende og empirisk påstand end bare at sige, at de psykologiske teorier er historiske, hvad de jo selvfølgelig er.

Jeg har her gennem mange år været i en kritisk dialog både med kulturpsykologiske aktørperspektiver, hvor subjektet synes at smelte sammen med de kulturelle betydninger, aktørerne frembringer og med poststrukturalistiske forståelser, hvor subjektet tenderer mod at forsvinde i sproglige strukturer og magtens cirkuleringer (se fx Nielsen 1994, 1999, 2000, 2013; Haavind og Nielsen 2010). Jeg forstår det kulturelle og det personlige som to analytiske niveauer, som hverken er radikalt adskilt eller reducerbar til hinanden. Som den amerikanske socialantropolog Michelle Z. Rosaldo har formuleret, er kultur ikke "[...] personality writ large" (1984: 141) eller menneskers indre verden: "[...] culture in miniature (Ibid.)". Det kulturelle medieres altid gennem personlig erfaring på samme tid, som det personlige aktualiseres og får form i bestemte kontekster. Spørgsmålet er dermed, hvordan det kulturelle og det personlige er gensidigt konstituerende i processer, der uophørligt transformerer begge dele.

Interessen for at forstå forholdet mellem subjektivitet, køn og kultur har altså rejst spørgsmålet om tid. Subjektivitet kræver en krop og et levet liv - et tidsperspektiv. Det samme gør indsigten $i$, at kontinuitet og forandring ikke udelukker hinanden. I den forstand er Chodorows rummobiliserende metafor: "[...] det sted hvor selvet møder verden” (1999:6) kun delvis dækkende. For det 'selv' og den 'kultur', der møder hinanden er i stadig ændring, og de ændringsprocesser går ikke nødvendigvis i takt, men er som oftest prxget af det, man kalder samtidighedernes usamtidighed. Alligevel 
kan vi heller ikke skifte rum ud med tid, for et møde foregår jo altid et sted.

\section{Historie OG ANTROPOLOGI}

Det er en udfordring at holde tid og rum i hovedet samtidig. Den norske kulturhistoriker Helge Jordheim (2012) har peget på det spejlvendte forhold mellem socialantropologi og de historiske discipliner. Mens historikeren skriver i datid, har antropologiens særegne grammatiske og stilistiske form været den "etnografiske nutid", som er knyttet til feltarbejderens ophold i den kultur, hun eller han studerer. Det giver et levende nærvær i beskrivelserne, men bringer også en tendens med sig til at se det aktuelle samfund løsrevet fra den historiske tid og ikke mindst at skygge for de ændringsprocesser, som er i gang i samfundet selv. Selvom den synkrone tid som punkt eller tværsnit gennem historien kan være fuld af liv, tenderer den også mod noget fastfrosset og ubevægeligt, mens længdesnittet gennem historien får bevægelse, proces og ændring frem, selvom det ofte er baseret på støvede kilder (Jordheim 2012:58-59). Til gengæld kan man sige, at antropologernes synkrone rum gennem den mere detaljerede og mangfoldige udforskning, som forskerens nærvær muliggør, vinder i kompleksitet og heterogenitet, mens historikerne ofte ender op med ganske afgrænsede og homogene rum, fordi den kumulative og diakrone historie forstås indenfor bestemte geografiske, kulturelle og nationale grænser (Ibid: 60). Som Jordheim opsummerer det:

Å tenke historisk i kategorier som utvikling, framvekst, begivenhet, kontinuitet, endring, varighet, brudd, stabilitet etc. er en utfordring for antropologien; å tenke kulturanalytisk, i kategorier som likhet og forskjell, identitet, innsider og utsider, grenser, strukturer etc. er en like stor utfordring for historievitenskapene. Antagelig har det noe å gjøre med hvordan forskere fra de respektive fagtra- disjoner er vant til å forestille seg tid og rom, og ikke minst forholdet mellom dem. (Ibid).

\section{BØRN I TID OG RUM}

I børne- og ungdomsforskningen kender vi denne diskussion mellem det synkrone og det diakrone som diskussionen om, hvorvidt barnet skal studeres som en væren eller en bliven - altså en 'being' eller en 'becoming' (James \& Prout 1990). Debatten blev rejst som en kritik af udviklingspsykologiens og socialiseringsperspektivets syn på børn som ufærdige voksne, altså 'becomings', og ikke som fuldværdige sociale deltagere, altså 'beings'. Denne vending fra omkring 1990, som endnu går under navnet the new sociology of childhood, var stærkt inspireret af det Clifford Geertz kalder etnografiens "tykke beskrivelser" af socialt liv (1973:10). Men da det etnografiske feltarbejde blev adopteret af sociologien, var det primært som en metodisk tilnærmning, og dermed blev det synkrone perspektiv endnu stærkere. Sociologer opholder sig jo betydelig kortere tid i felten, end antropologerne trods alt gør det. Det skal selvfølgelig tilføjes, at den nye barndomssociologi også understregede betydningen af et historisk perspektiv, men dette gjaldt ikke børnene selv, men i stedet den måde strukturelle rammer og samfundsmæssige forestillinger om barndom ændrer sig historisk. På den ene side studiet af levende børn nu og her og på den anden side studiet af, hvordan barndom som sted og begreb konstrueres historisk. Den historiske dimension knyttet til individernes udvikling blev altså borte.

Slagordet om at børn skulle studeres som 'beings' blev imidlertid hurtigt overhalet af den essentialismekritik, der voksede frem i løbet af 1990erne gennem den poststrukturalistiske videnskabskritik. Kort fortalt: ingen er "beings", heller ikke de voksne og slet ikke i det senmoderne samfund, som kræver fleksibilitet og konstant omstillingsparathed af sine medlemmer. Men først og fremmest blev essentia- 
lismekritikken koblet til en ontologisk påstand om, at alle fænomener altid er i en tilstand af tilblivelse på komplekse og delvis uforudsigelige måder. Barn eller køn er ikke noget man er, men noget man gør, som det hedder. Gennem disse mangfoldige processer skabes der imidlertid ikke subjekter, det ville jo være en essentialistisk tanke. Det er magten, der fremkalder og former de menneskelige handlinger den cirkulerer gennem, og magten bliver dermed det egentlige subjekt i analysen. Man snakker ikke om subjekter, men om subjektiveringsprocesser og disse repræsenterer altså en af magtens mikroprocesser, sådan som Michel Foucault og Judith Butler har beskrevet det for os. Indenfor en sådan teoretisk ramme flyttede begrebet om 'becoming' fra en funktionalistisk eller udviklingspsykologisk referenceramme til en forestilling om evig tilblivelse - til rummet for the no longer and the not yet, som det ofte formuleres ( $\mathrm{fx}$ Lather 2007).

$\mathrm{Nu}$ kan man jo indvende, at noget der fortsætter i det uendelige egentlig tenderer mod at være ligeså tidsløst som det evige nu. Det er fx en kritik, der er rejst af den engelsk sociolog Lois McNay mod Judith Butler, som hun mener tenderer mod at konstruere køn, som det hun kalder " [...] et relativt atemporalt system af dominerende normer" (McNay 1999: 102), som hverken medieres gennem agency eller praksis. En anden engelske sociolog, Emma Uprichard, har på samme måde kritiseret den nye barndomssociologi for at forstå børns opvækst kun som en bevægelse gennem forskellige sociale ordner i stedet for som en bevægelse gennem tid (Uprichard 2008: 307). Dette lyder måske lidt paradoksalt, fordi der i poststrukturalistisk tænkning netop er så stor vægt på proces og tilblivelse, og det er jo temporale begreber. Men her minder det faktisk om den antropologiske presentisme: den kulturelle orden, som skabes i det synkrone nu, bliver til gennem aktørenes altid igangværende meningstolkninger og interaktion med hinanden.
I stedet for at snakke om tid og rum er det derfor måske mere frugtbart at skelne mellem to slags temporaliteter her: på den ene side tid forstået som noget fremadskridende og kumulativt (kroppens vej fra fødsel til død) og på en anden side tid forstået som forhandlings- og resignifieringsprocesser $i$ øjeblikkets rum. Dermed kan vi i stedet for at vælge mellem dem snarere stille spørgsmålet: Hvordan samvirker disse temporaliteter? Hvordan kobles øjeblikkets tilblivelsesprocesser med historisk og biografisk akkumuleret erfaring og aktørenes forventninger til fremtiden? For at vende tilbage til Jordheims diskussion af synkron og diakron tid: Det synkrone øjeblik er fyldt op af erfaringer, genstande og praksisser, som er usamtidige med hinanden, fordi de hører hjemme i forskellige diakrone sammenhænge og processer.

Jeg vil tilføje, at en sådan sammenkobling også er betingelsen for at forstå samtidigheden i kontinuitet og forandring og for at forstå, at vi ikke behøver vælge mellem subjektforståelser, der enten ser subjektet som en ahistorisk, essentialistisk, cartesiansk størrelse eller som opløst i sprogets og magtens mikrodynamikker. Det bliver tydeligt, når man følger individer gennem forskellige situationer og over tid. Den teoretiske forståelse făr altså metodiske konsekvenser - og omvendt. Jeg vil i det følgende give et eksempel på, hvordan denne usamtidighed mellem lineær og fremadskridende tid, og de stadigt nye forhandlingsprocesser i øjeblikkets rum, viser os samtidigheden mellem forandring og kontinuitet. Jeg henter eksemplet fra mit longitudinelle skoleprojekt (Nielsen 2011/2009) og tager et lille udsnit af, hvordan ét barn xndrer sig over 8 år, men alligevel i en anden forstand forbliver den samme.

\section{ASTRID GENNEM TID OG RUM}

Fra første skoledag fremstod Astrid for mig som et aktivt, udadvendt og viljestærkt barn. Hun opfattede ofte ting som uretfær- 
dige og dumme eller opgaverne og lektierne som for svære og gav højlydt udtryk for dette i klassen. I de første skoleår korrigerede og moraliserede hun konstant overfor både klassekammeraterne og lærerne, samtidig med at hun selv brød de selvsamme regler. Hun var meget tit i centrum for den uro, der kunne opstå i klassen, eftersom hun var stærkt orienteret mod og også tiltrukket af sociale relationer, men ikke håndterede dem med nogen særlig finesse. Hun mindede mig ofte om en elefant i en glasbutik, når hun med et lidt overrasket og såret blik blev konfronteret med al det knuste glas omkring sig.

\section{KLASSE, FJERDE SKOLEDAG, 7 ÅR GAMMEL:}

Astrid beklager sig over at alle hendes tusser er tørre. "Også mine” siger Kristin, og de to piger fordyber sig i en samtale om tusjsituationen. Læreren minder hende om at de skal have "lynlås for munden". Astrid vender sig om mod Nina som ikke har sagt en lyd hele timen og hvisker: "Husk lynlåsen!".

Siden jeg kun så Astrid i skolesammenhæng, ved jeg ikke, hvorfor hun forholdt sig til verden på denne måde, men over tid kom jeg til at se det som et genkommende mønster i hendes måde at relatere sig til andre på. Men jeg så også, at dette mønster fik stadigt nye former og betydninger, som hun blev xldre. Man kan beskrive det sådan, at hun hele tiden skabte nye versioner af sin særlige relation til omverden gennem at reagere på andre og ud fra sine voksende kognitive og sociale kompetencer. Hun voksede altså gennem at tilføje stadigt nye lag til sin subjektivitet, men forblev alligevel genkendelig som person. For eksempel rettede hun efterhånden sin relationelle strategi mod især at drille drengene:

\section{KLASSE, 9 ÅR GAMMEL:}

Ola er i skole i dag efter at have været væk nogle dage. Astrid siger til ham: "Der var fred og ro i klassen, da du var væk, at du ved det!" Ola (fredeligt): "Ja, det er klart.” Astrid: "Ved du selv, at du larmer?" Ola: "Det gør du da også!” Astrid tager fat i armen på ham og trækker til. Hun truer (halvvejs for sjov) med at banke ham i frikvarteret. Ola og Halvor ler. Astrid tager igen fat i Olas trøje - han protesterer - den er ny og kan blive ødelagt! Astrid: "Det vil jeg skide på!” Læreren kommer og beder Astrid om at tage skoene af. Astrid rejser sig, mens hun mumler: "Lærere ser da også alting!” Da hun passerer Halvor, siger hun: "Halvor! Tag dine sko af?"

Astrid lærte også, hvordan man drev lærere til vanvid. Fra 4. klasse excellerede hun i denne sport og fik flere og flere irettesættelser fra lærerne. I løbet af indskoling og mellemtrin blev hun stadigt mere højrøstet, ironisk og forstyrrende især overfor andre lærere end klasselæreren. Hun klarede sig imidlertid ganske godt fagligt set, og hun var med i pigegruppen, selvom de nogen gange sukkede over hende. Astrids støjende opførsel nåede et højdepunkt i 6.klasse. Hun var nu den højeste i klassen, havde en forholdsvis dyb stemme og var meget synlig og hørbar, hvor hun end var. Mens en del af de andre piger nu var begyndt med modetøj og striber i håret, lignede Astrid mere drengene med sit korte hår, store løse sweatshirts, kamuflagebukser og joggingsko. Men tiden var ved at løbe ud for den slags opførsel. Det kulturelle køn lurede i horisonten på nye måder. Selvom drengene var mindre modne og små af vækst, var de ved at opdage et våben, som lå udenfor det ligestillingsregime, de hidtil var vokset op i: nemlig drengegruppens kollektive seksualisering af pigernes kroppe. Jeg hørte, at de var begyndt at kalde Astrid for "puta”, dvs. luder på spansk, og det var et angreb, hun havde sværere ved at turnere, end når hun sloges fysisk med drengene. En dag fandt jeg Astrid grædende på pigetoilettet: 


\section{KLASSE, 12 ÅR GAMMEL:}

Astrid sidder på pigetoilettet og stortuder, mens Tirana og Ida prøver at trøste hende. Hun fortæller hikstende, at drengene er efter hende og siger, at hun ligner en mand, at hun taler som en mand og opfører sig som en mand. Det har de gjort længe, og nu kan hun ikke holde det ud mere! Det er ikke, fordi hun vil være en dreng, at hun går i store løse sweatshirts, men fordi hun godt kan lide det! Hun har sorte striber ned ad de våde kinder og det går pludselig op for mig at hun bruger mascara. Jeg lægger også mærke til den feminine top hun har på under den grove sweatshirt (...) Efter timen spørger læreren hende hvorfor hun var blevet ked af det. Astrid fortæller det og smiler lidt da læreren siger: "Du ligner overhovedet ikke en dreng, du ligner Astrid!”

Denne begivenhed, og sandsynligvis andre som jeg ikke observerede, så ud til at føre til en energisk resignifiering af Astrids relation til andre og til sig selv. Da jeg ankom til min årlige observationsuge et år senere, kunne jeg knapt genkende hende, da hun langsomt skred op af trappen iført stramme sorte jeans, en sort kropsnær bluse, pink skindjakke og et lille tørklæde om halsen, håret tonet rødligt og samlet bagtil i en lille hestehale, langt pandehår og solbriller $\mathrm{i}$ panden, selvom det fortsat var vinter. De andre piger havde også skiftet stil, mens drengene stadigvæk var små at se til. Astrid var klart ledende sammen med en anden ny pige i klassen. Man hørte konstant de to i klasseværelset mest på grund af deres morsomme bemærkninger, dovne protester og spillen fornærmede. Gennem udskolingen kombinerede Astrid sin fysiske styrke og kompetence både med gode skolepræstationer og med et xggende kropssprog og en flirtende stil overfor både de unge mandlige lærere og drengene:

\section{KLASSE, 14 ÅR GAMMEL:}

Uden for naturfagslokalet ser jeg Astrid holde
Håkon i et jerngreb. Han hævner sig, hun skriger højt og ler. Sender ham et stort, strålende smil [det har jeg aldrig set før!]. Håkon bliver ved med at angribe hende, mens de går ned ad trappen til kantinen. Hun ler og smiler, slår igen, men på en lidt doven, flirtende måde. Nede i kantinen sætter hun sig ved et bord, bevæger sig til musikken, møder Thomas' blik, puffer kærligt til ham. Han virker meget interesseret $i$ hende, ser hele tiden betaget på hende. Hun bruger blikket, smilet, kommentarerne på en dreven måde, er både aktiv og forførende. Hun behersker både drengerepertoiret og en feminin heteroseksuel kode og det giver hende magt. Hun får meget opmærksomhed fra Thomas, Håkon og Chris, og det er hende, der fører an i spillet. "Sagde du noget om mig", siger hun sløret til Chris. "Sagde du noget lort om mig?"

Astrid har altså tilpasset sig forventningerne til, hvordan en 14-15 årig pige skal være på dette sted til denne tid, men samtidig formår hun at beholde sin magtposition ved at skifte våben fra kamp til seksualiseret flirt. Vi kan måske se, hvordan hendes øvelse i kamp og konflikt gennem barndommen, sammen med den kundskab hun har erhvervet sig om drengenes verden, giver en solid basis for denne strategi. Men hun giver også udtryk for sårbarhed bag det forførende spil. Det er hårdt arbejde, at holde kontrollen og i et interview i 8. klasse siger hun, at kampen er ulige, fordi drengene kan bruge andre metoder. Hun føler heller ikke, at hun kan have hele sig selv med i sin nye forførende stil. I interviewet antyder hun endnu en resignifiering, og hun trækker på en ligestillingsdiskurs for at forstå og udtrykke sin oplevelse af, at noget ikke stemmer:

INTERVIEW MED ASTRID, 8. KLASSE, 15 ÅR GAMMEL:

(...) Jeg ved at jeg også nogen gange har været ret flabet, men du får det jo bare dobbel tilbage. Så da er det jo lidt håbløst. Jeg sy- 
nes ikke altid at jeg kan være mig selv og sige hvad jeg vil, for jeg er bange for at de vil komme med spydige bemærkninger, men... (...) Der er mange af drengene i vores klasse som ikke har forstået hvad kvindeundertrykkelse er. De er skide ligeglade.

Disse korte glimt af Astrids udvikling fra barn til ung viser, hvordan kontinuitet ikke udelukker forandring. Hun forhandler konstant om, hvem hun er og kan være i de situationer hun er i, hun lærer nye måder at gøre ting på, griber nye kulturelle former at udtrykke sig gennem, og hendes selvfortælling skifter undervejs. Hendes stadigt nye resignifieringer mødes og evalueres af hendes omgivelser. Klassekammeraterne giver hende feedback på den måde, hun opfører sig på, og den måde hun iscenesæetter sit køn på. Det samme gør lærerne. I indskolingen og på mellemtrinnet synes de, at hun er for meget og definerer hende som en problemelev. På udskolingen passer hun tilsyneladende bedre med tidens diskurser om 'de nye, stærke piger' og lærernes bekymringer forsvinder. Hun "er Astrid", fortæller de mig, viljestærk og temperamentsfuld og en fagligt stærk elev (og hvis vi følger hende videre finder vi hende som 23årig i form af en energisk, målrettet og ambitiøs ung kvinde, der er i færd med at uddanne sig som organisationspsykolog, og som allerede er blevet headhuntet til flere projekter af store firmaer).

Men til trods for alle disse reforhandlinger og denne stadige tilblivelse forbliver hun også genkendelig som person med sin styrke og sit særlige konfliktfyldte forhold til verden. Hendes løsninger i forskellige aldre kan tolkes som bevidste, før- og ubevidste resignifieringer af, hvem hun kan være $\mathrm{i}$ forhold til andre. En tilsyneladende tidløs og stabil konfliktbetonet relation til omverdenen leder altså til stadig nye versioner af dette forhold. Men det er også sandsynligt at disse resignifieringer efterhånden vil modificere og transformere denne grundlæggende konflikt - hvad end den nu handler om. Fortiden er ikke bare et bagtæppe for aktuelle hændelser, men noget som også selv gradvist bliver rekonstrueret gennem disse hændelser, men i et lidt anden tempo og dynamik. Mit indtryk af Astrids energiske investering i sin uddannelse og karriere da jeg møder hende som 23-årig kan tyde på en mere grundlæggende ændring, hvor den kraft, der tidligere blev kanaliseret ud i konflikter med andre, nu retter sig mod konstruktive aktiviteter, som giver hende stor tilfredsstillelse og samtidig lader hende være det særlige subjekt, hun er blevet til gennem sin biografiske livsbane.

\section{TIDENS PIL}

Det jeg har villet vise med Astrid som eksempel er, at udviklingsbegrebet, eller et begreb om en lineær og kumulativ tid, ikke nødvendigvis implicerer determinisme eller universalisme. I stedet for de klassiske udviklingspsykologiske modeller kan vi forstå den lineære tid gennem metaforen 'tidens pil': et begreb som blev udviklet indenfor astronomi og fysik i 1920erne, og som griber tidens ensrettethed. Det populære billede er, at you can't unscramble eggs. Så selvom der er noget gentagende ved Astrids resignifieringer, indgår de også i en fremadrettet tidslinje, og det er ikke muligt at tænke sig et omvendt forløb mellem de fem observationer, jeg har vist af hende. Uanset hvordan vi konstruerer børn og barndom bliver børn store, mens voksne ikke bliver små $\mathrm{i}$ andet end metaforisk forstand.

Den franske filosof Henri Bergson siger, at fortiden er betingelsen for enhver fremtid, men at den fremtid som kommer, alligevel kun er en af de mange muligheder som lå i fortiden (Grosz 2004, 184). Og det er jo en pointe, vi også finder hos den samtidige Sigmund Freud. Bergson er interesseret i udvikling og i bevægelsen fremad i tid. Han forstår fremtiden som baseret på fortidens ressourcer, men også som noget, der overskrider disse ressourcer gen- 
nem innovation og kreativitet. Fortiden er magtesløs, hvis den ikke kobles til en perception i nuet, som kan mobilisere den i handling:

[... we may speak of the body as an ever advancing boundary between the future and the past, as a pointed end, which our past is continually driving forward into our future.

Whereas my body, taken at a single moment, is but a conductor interposed between objects which influence it and those on which it acts, it is, on the other hand, when replaced in the flux of time, always situated at the very point where my past expires in a deed (Bergson 1911: 88).

For Bergson er dette kreative potentiale i nuet koblet til kroppens kapacitet til at lagre energi og hukommelse og for at kunne forholde sig vælgende til, hvornår energien udlades i en respons på en perception i nuet. På den måde kan han beholde et begreb om linearitet mellem fortid og fremtid, men uden at ende op i lineær determinisme.

Gennem tidens pil skabes historie, kollektiver og subjekter. Når det gælder subjekter, er det, der bevæger sig med tidens pil ikke kun den biologisk modning, men også en lang række andre sociale og udviklingsmæssige processer, der interagerer med hinanden og skaber et dynamisk samspil mellem tid og rum - sådan som vi så det $\mathrm{i}$ tilfældet med Astrid. Forstået på den måde kan man også generobre et begreb som udviklingspsykologi som noget, der sker gennem relationer og over tid (Halldén 2007: 36). I stedet for at smide udviklingspsykologien på videnskabens køkkenmødding, sådan som forfægterne for den nye barndomssociologi gjorde, kan vi snarere decentreve dens autoritet. Vi kan anvise den en mere beskeden plads som en forståelse af en delvis biologisk betinget kognitiv modningsproces, der spiller sammen med andre sociale, kulturelle og emotionelle processer, men alligevel beholde dens indsigter som en brik af det store puslespil. Mine fund i Skoletid giver i hvert fald mening i et sådant let revideret perspektiv.

Disse ideer om kropslig energi og hukommelse, og den måde den retter sig mod en uafgjort fremtid, er også blevet taget op af post-poststrukturalistiske teorier om affektivitet, fx hos Deleuze \& Guattari (1988/1980) og hos Brian Massumi (2002). Men her mangler netop den kobling til fortiden, som Bergson understreger og også det aktivt handlende subjekt, han opererer med. Bergsons stærke kritik af associanismen (se Bergson 1911) synes at have gået både Deleuze og de nyere affektteoretikere hus forbi. Så i stedet for at læse Bergson gennem en poststrukturalistisk performativitetslinse, sådan som det er mest udbredt, foretrækker jeg at læse ham gennem en hermeneutisk linse, som vægtlægger betydningen af det aktivt fortolkende subjekt (med tråde til fx Ricouer, Benhabib, Giddens, Chodorow, Layton). Det der adskiller denne subjektforståelse fra den poststrukturalistiske evige tilblivelse er to ting:

For det første at subjektets fortolkning af sig selv forstås på en og samme tid som både formativ og transformativ, fx som noget, der fører til ændring, men som også holder subjektet sammen, fordi interaktionserfaringer sedimenteres over tid og bliver til subjektivitet. Det vil sige, at ændring og kontinuitet ikke er uforenelige, og at det at operere med et begreb om selvet ikke nødvendigvis implicerer essentialisme. Som den amerikanske filosof og kønsforsker Seyla Benhabib siger:

“[... ] identity does not mean 'sameness in time' but rather the capacity to generate meaning over time so as to hold past, present, and future together" (Benhabib 1999: 353).

For det andet at denne konstruktion af en narrativ identitet både har bevidste og ubevidste dimensioner. For at blive ved Benhabib: 
"Every story we tell of ourselves will also contain another of which we may not even be aware; and, in ways that are usually very obscure to us, we are determined by these subtexts and memories in our unconscious" (Ibid: 349).

Et sådan tidsbegreb kan også kobles til psykoanalysens forståelse af de forskellige typer psykiske og temporale processer, der findes i menneskers psykiske liv. Psykoanalysen dobbelte tidsbegreb gribes i afforismen om, at den analytiske behandling er færdig, når patienten forstår, at den kunne fortsætte i det uendelige. På den ene siden har vi altså primærprocessernes og det ubevidstes tidsløshed karakteriseret ved stadigt cirkulerende forskydninger og fortætninger af mening - altså en type processer, som minder om det, jeg har kaldt resignifieringer i øjeblikkets rum. På den anden side sekunddærprocessernes realisme og kronologi. Udviklingen af sekundærprocesser er et uomgængelig forhold, eftersom det er forudsætningen for at forholde sig til andre mennesker som adskilte væsener.

Børn vokser gennem sine sociale og emotionelle relationer og siden der ikke findes relationer uden konflikt, vil et realitetsprincip altid være en del af en tilbliven. Og det er jo netop derfor jævnaldergruppens intense samvær er så afgørende for børns psykologiske og sociale udvikling. Der er altså en sammenhæng mellem erfaring, tid og subjektdannelse. Den engelske psykoanalytiker Rozine Perelberg siger det på denne måde: "Når jeget entrer scenen, dukker tid og historie ogsà op for forste gang (2008: 26 - min oversættelse)”. Dynamikken mellem de to temporaliteter gribes også i begrebet om Nachträchligket, der er beskrivende for, hvordan en tidligere erfaring kan få ny mening, refortolkes i lyset af nye erfaringer eller ud fra senere modenhedsniveau. Resignifieringen forbinder dermed fortid, nutid og fremtid og Astrids biografiske "plot" eksisterer dermed i mange versioner tilsvarende hendes udviklings- niveau og aktuelle livsomstændigheder. På den måde kan man sige, at resignifieringsprocesser og lineær tid ikke er alternativer, men konstituerer hinanden gensidigt.

\section{KøN I TID OG RUM}

Lad mig afslutningsvis antyde, hvordan disse perspektiver også kan bidrage til at forstå køn i et mere overordnet socialt og historiske perspektiv. Kønnets samtidige usamtidigheder - både når det gxlder forskellige sociale grupper, som lever på samme tid, og når det gælder kønnets forskellige dimensioner - kommer også til syne, når de studeres over tid. Det bliver tydeligt, at kønnet subjektivitet ikke er en bestemt indholdsmæssige størrelse fx kendetegnet af omsorgsevne og bløde værdier, eller hvad man nu kunne finde på at koble til kvindelighed, men at den kønnede subjektivitet bliver til noget bestemt i hvert enkelt liv, fordi den skabes af et kulturelt kønnet stof og gennem kønnede relationer (Nielsen 1994, Chodorow 1999). Køn konfigureres dermed forskelligt for den enkelte, men det betyder ikke, at der ikke også kan findes familieligheder i de kønnede subjektiviteter mellem mennesker, som lever på samme sted og som deler køn og alder.

Et eksempel på dette kan være de forskellige kønspolitiske standpunkter som var til stede blandt yngste generation i vores tregenerationsstudie (Nielsen \& Rudberg 2006) - fx om de unge kvinder var mest tiltrukket af ligestillingsfeminisme eller forskelsfeminisme. Analyseret synkront fremstod det som forskellige principielle politiske standpunkter. Mens hvis det sættes ind i et generationsperspektiv, så kompliceres billedet af, hvilke dimensioner af kønnet ligheden og forskellen gxlder for de unge kvinder. Og det viser sig, at positionerne ikke bare hviler på fornuftmæssig refleksion, men at de har stærke subjektive og emotionelle føringer, som bl.a. kan handle om hvilke emotionelle kvaliteter, der bevidst eller ubevidst gennem livhistorien, er blevet 
koblet til billeder af mandlighed og kvindelighed. Den betydning kønnet har fået i de nære relationer har igen en affinitet til men er ikke determineret af - den sociale kontekst. På den måde fletter subjektivitet, køn, social mobilitet og social ændring sig sammen gennem individers livshistorier og bidrager til at skabe den store historie. At bevægelsen ikke bare går én vej, altså fra de store strukturer til de enkelte liv, men også fra det enkelte liv til de store strukturer, blev synligt, netop fordi vi kombinerede et generationsperspektiv med et longitudinelt design for yngste generation. De konflikter de unge kvinder snakkede om som 30-årige, altså i 2001, hvor de havde gjort sig sine første erfaringer i uddannelse, familie og arbejde handlede i høj grad om dilemmaer, som faktisk først det følgende årti kom på den offentlige og politiske dagsorden. Det var de vanskelige punkter i den nordiske ligestillingsmodel knyttet til at livet ofte bliver for stresset $\mathrm{i}$ den moderne familie, at det også kan være kvinders egne valg der bidrager til kønsulighed, at der er for lidt fokus på mændenes situation i ligestillingspolitikken, at omsorgsværdier ofres på det moderne forbrugs alter, og at ligestilling indenfor arbejde og politik måske godt kan kombineres med at hengive sig til kønsforskel på andre af livets områder. På forskellige måder tematiseres altså denne generations krav om at ligestillingspolitikken må have rum for mere personlige og forskellige valg som resultat af oplevede dilemmaer $i$ eget liv.

\section{AFSLUTNING}

Jeg vil afslutte med endnu engang at vende tilbage til Helge Jordheims overvejelser over antropologiens evne til at aflæse komplekse rum og historievidenskabernes evne til at forstå de lange bevægelser. Han skriver, at begrebet historicitet måske er det, der bedst markerer grænsesnittet mellem antropologi og historie. Han henviser her til Augustins forståelse af historicitet som den sammensmeltning af fortid, nutid og fremtid, som sker gennem et erfarende, reflekterende og handlende subjekt. Og han citerer antropologerne Hirsch \& Stewart, som også taler om den komplekse temporale nexus af fortid-nutid-fremtid: " $H \mathrm{His}^{-}$ toricity' describes a human situation in flow, where versions of the past and future (of persons, collectives and things) assume present form in relation to events, political needs, available cultural forms and emotional dispositions” (2005: 262). Astrid og de unge kvinder $\mathrm{i}$ generationsstudiet har fortiden $\mathrm{i}$ sig, ikke som noget determinerende, men som noget, der gør, at de i forskellig grad og på forskellige måder responderer på nye erfaringer, at de går videre og erobrer nye måder at tænke på. De bliver på denne måde i stand til kreativt at skabe fremtiden og til at ændre eller videreføre kønspraksisser både $\mathrm{i}$ deres eget liv og som politiske subjekter.

\section{Noter}

1. For eksempel disse projekter: Kjønnssosialisering $i$ et utviklingspsykologisk perspektiv (se Nielsen \& Rudberg 1989), Ungdom i tre generasjoner (se Nielsen \& Rudberg 2006), Jenter og gutter fra 1.9.klasse (se Nielsen 2011/2009) og Nye kjønn, andre krav? Likestillingens barn i skole og familie (se Nielsen 2014)

\section{LITTERATUR}

- Benhabib, Seyla (1999): Sexual Difference and Collective Identities: The New Global Constellation. Signs, 24(2):335-361.

- Bergson, Henri (1911): Matter and memory.

George Allen \& Unwi, London.

. Chodorow, Nancy (1999): The Power of Feelings.

Yale University Press, New Haven.

- Deleuze, Gilles \& Guattari, Felix (1988/1980):

A Thousand Plateaus. London

. Geertz, Clifford (1973). The Interpretation of Cultures. Basic Books.

- Grosz, Elizabeth (2004): The nick of time: politics, evolution, and the untimely. Duke University Press, Durham. 
- Hirsch, Eric \& Stewart, Charles (2005): Introduction: Ethnographies of Historicity.

History and Anthropology, 16(3): 261-274.

- Haavind, Hanne \& Nielsen, Harriet Bjerrum (2010): Personal development and socio-cultural change. Proposal for a reseach group at the Centre for Advanced Study (CAS) 2010-2011. Project abstract: http://www.cas.uio.no/research/101lpersonaldevelopment/Abstract.pdf

- James, Allison \& Prout, Alan (1990): Constructing and reconstructing childhood. Falmer Press, London.

- Jordheim, Helge (2012): Øyeblikkets historie.

Norsk Antropologisk Tidsskrift, 23(1):55-65.

- Lather, Patty (2007): Getting lost. Feminist efforts toward a double(d) science. University of New York Press, Albany State.

- Massumi, Brian (2002): Parables for the virtual: movement, affect, sensation. Duke University Press, Durham.

- McNay, Lois (1999) Gender, habitus and the field. Pierre Bourdieu and the limits of reflexivity. Theory, Culture \& Society, 16(1), 95-117.

- Nielsen, Harriet Bjerrum \& Rudberg, Monica (1989): Historien om jenter og gutter. Universitetsforlaget, Oslo.

- Nielsen, Harriet Bjerrum \& Rudberg, Monica (2006): Moderne jenter. Tre generasjoner på vei. Universitetsforlaget, Oslo.

- Nielsen, Harriet Bjerrum (1994): Den magiske blokk - om kjønn og identitetsarbeid. Psyke \& Logos 15(1): 30-46.
- Nielsen, Harriet Bjerrum (1999): 'Black holes' as sites for self-constructions. In R. Josselson \& A.Liblich (eds.): Making Meaning of Narratives. Sage, London.

- Nielsen, Harriet Bjerrum (2000): Rommet mellom sitering og dekonstruksjon. Kvinneforskning 1: 16-29.

- Nielsen, Harriet Bjerrum (2011/2009): Skoletid. Piger og drenge fra 1. til 9.klasse. Akademisk forlag, København.

- Nielsen, Harriet Bjerrum (2013): At blive, gøre, være og udfordre køn. In M.H.Jacobsen, E.Laursen \& J.B.Olsen (red.): Socialpsykologi. Hans Reitzels Forlag, København.

- Nielsen, Harriet Bjerrum (red.) (2014): Forskjeller $i$ klassen. Kjønn, klasse og etnisitet $i$ skolen $i$ dag. Universitetsforlaget, Oslo.

- Rosalso, Michelle Z. (1984): Towards an anthropology of self and feeling. In R. A.Schweder \& R. A. LeVine (red.): Cultural theory: Essays on mind, self and emotions. Cambridge University Press, Cambridge.

- Rudberg, Monica \& Nielsen, Harriet Bjerrum (2012): The making of a 'new man'. Journal of Psycho-Social Studies, 6(1), 55-74.

- Uprichard, Emma (2008): Children as 'Beings and Becomings': Children, Childhood and Temporality. Children and Society 22: 303-313.

Harriet Bjerrum Nielsen, professor Senter for tverrfaglig kjønnsforskning Oslo Universitet 